\title{
Global Climate Change in the Wider Context of Sustainability
}

\author{
Walter R. Stahel \\ The Geneva Association, 53, rte de Malagnou, Geneva 1208, Switzerland. \\ E-mail: walter_stahel@genevaassociation.org
}

Over the last few years, the political discussion on global change has become focused on the Intergovernmental Panel on Climate Change (IPCC) reports and anthropogenic $\mathrm{CO}_{2}$ emissions, as well as on scientific data of climate change, and on new rules and regulation. This paper puts $\mathrm{CO}_{2}$ emissions into the wider context of sustainability. This broadens the view and changes the focus to issues of global ethics and the necessity for industrial countries to drastically reduce their resource consumption. Insurance companies can influence global climate change (GCC) directly through their investment and underwriting strategies, but also in daily operations. An overview and examples are given in the paper. The biggest impact insurance might have is in helping to speed up the adaptation to GCC, for instance by making available its pool of knowledge in prevention measures through risk engineering services. By promoting a stricter application of the concept of "insurability of risks", politicians could exploit the link between insurance, technological innovation and sustainable development to develop numerous opportunities within the market economy. A rapid adaptation to the challenges of GCC will give industrialised countries a competitiveness pull, or enable less developed countries to leapfrog industrialised countries. But the key to a new vision of the future may be the development of a holistic view of nature, man and climate, and science and technology as a source of innovative ideas and solutions.

The Geneva Papers (2008) 33, 507-529. doi:10.1057/gpp.2008.21

Keywords: global climate change; $\mathrm{CO}_{2}$ emissions; sustainability; the role of insurance companies; opportunities in GCC; adaptation to GCC

\section{Introduction}

Global climate change (GCC) is an issue similar to safety. Both suffer from warning fatigue ("shouting wolf" when nothing happens or only others are affected) and from frustration if a loss materialises despite actions taken.

This paper looks at five spheres and how they are interlinked in the context of GCC: politics, ethics and media; ecology; global science; technology; and economy and insurance. The first three spheres have a global but somewhat abstract reach. Technology, and economy and insurance, by contrast, concern concrete measures in primarily industrialised countries. Each section can only give a summary of the issues

\footnotetext{
*Visiting Professor at the Faculty of Engineering and Physical Sciences, University of Surrey, Vice Secretary-General and Head of Risk Management Research at The Geneva Association.
} 
concerned; the focus of the paper is on a holistic view to identify reductions in resource consumption as key to anthropogenic GCC emissions.

Sustainable development is today's overall political guiding principle: a holistic and intertwined approach based on an equilibrium between economic, ecological and social issues, requiring responsible and ethical players. This paper claims that the key issue at stake is the unbalanced resource consumption on a global level, an issue of global ethics. The present GCC discussion, by contrast, is limited to reducing $\mathrm{CO}_{2}$ emissions from the burning of fossil fuels by man. This approach neglects the fact that reducing resource consumption always reduces $\mathrm{CO}_{2}$ emissions, whereas a focus on reducing $\mathrm{CO}_{2}$ emissions can lead to a higher ecological footprint (e.g. biofuels, carbon offsetting) or to increased resource consumption (e.g. exploiting wave and wind energy).

\section{The politics and ethics sphere}

\section{Politics}

The reports by the Intergovernmental Panel on Climate Change (IPCC) are an attempt to reduce a complex scientific issue to a politically manageable entity: man-made $\mathrm{CO}_{2}$ emissions. However, this view ignores Agenda 21, which was the main result of the 1992 UN Conference on Sustainable Development held at Rio de Janeiro. Chapter 8 of Agenda 21 exposes the global disparities - that 80 percent of the world resources are consumed by the 20 percent of the world's population living in the industrialised countries, and calls for equal access to resources for all world citizens (Figure 1).

Anthropogenic $\mathrm{CO}_{2}$ is only one of the greenhouse gases (GHG), but the one that can most easily be instrumentalised politically. $\mathrm{CO}_{2}$ is also emitted by nature in shorter-term natural cycles: biomass, such as trees, uses $\mathrm{CO}_{2}$ from the atmosphere to

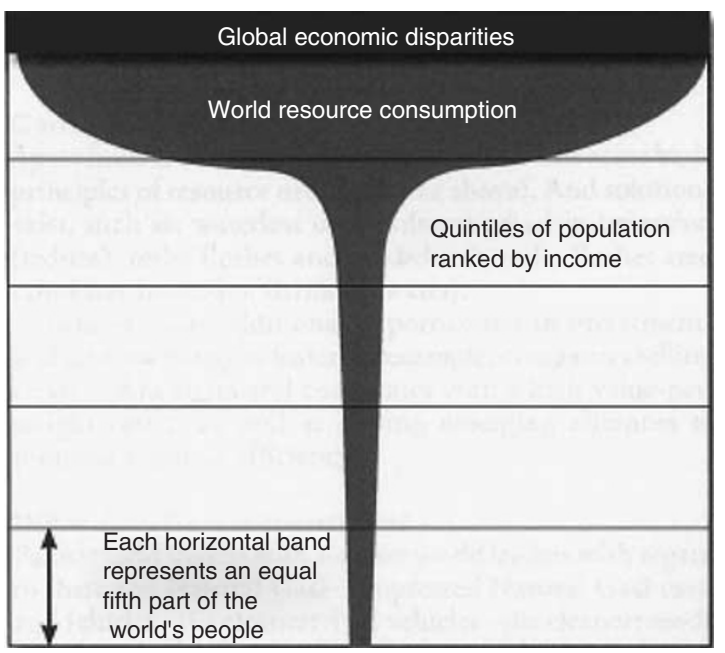

Figure 1. The champagne glass of non-renewable resource consumption in relation to the world population by income groups. Source: Chapter 8 of Agenda 21, UN Conference on SD, Rio de Janeiro, 1992. 
grow and then stores it in the trees' structure. When trees are felled and the wood is burned the $\mathrm{CO}_{2}$ is returned to the atmosphere. Oil, coal and gas, by contrast, are ancient biomass that has been stored underground for long periods of time and their carbon is emitted back into the atmosphere with a long time lag; they are part of an extremely long-term natural cycle. In addition, $\mathrm{CO}_{2}$ is also absorbed and emitted by the oceans, a mechanism governed by the oceans' water temperature.

The majority of GHG is not man-made but part of natural cycles with different durations. Water vapour is the dominating GHG by volume; methane is one of the most aggressive ones. But as water vapour is emitted by oceans and methane by natural processes, such as rice paddy fields and ruminants, it is difficult to reduce them through politics.

Now, if we accept that $\mathrm{CO}_{2}$ is the main trigger of climate change, then apartheid policies of $\mathrm{CO}_{2}$ reductions do not make sense - one $\mathrm{CO}_{2}$ molecule is equally bad as another. Its origin - transport (aircraft, truck, taxi, fishing vessel, automobile), heating and cooling (of buildings and spaces) or industrial applications - has no influence on its negative impact on the climate. Differences in taxation - and subsidies of $\mathrm{CO}_{2}$ emissions - are therefore nonsense! Yet today only few of the above $\mathrm{CO}_{2}$ emitter sources are taxed equally. Aircraft on international flights pay no taxes on kerosene at all; electricity prices for industry are a fraction of those for households; fishermen, taxi drivers and haulage companies are exempt from VAT and duties or levies on diesel fuel in many industrialised countries. Regular strikes, for instance by Paris taxi drivers, allow them to maintain this privilege.

The list of unsustainable subsidies in OECD countries is headed by road transport and agriculture - abolishing subsidies of $\mathrm{CO}_{2}$ emissions would seem an easy first political step. Promoting sufficiency solutions and reduced consumption, which are basic strategies of any sustainable development and have a substantial potential for reducing $\mathrm{CO}_{2}$ emissions, would seem equally obvious - but sufficiency has no political lobby.

Also, if we accept that $\mathrm{CO}_{2}$ is the main trigger of climate change, all reductions in $\mathrm{CO}_{2}$ emissions should be rewarded equally. However, under the Kyoto Agreement, $\mathrm{CO}_{2}$ credits to economic actors are only given for emission reductions in production (e.g. a power station reducing its emissions through clean technology), not for reductions through prevention measures or through business models focused on safeguarding embodied $\mathrm{CO}_{2}$ stock, such as the management of physical assets. This issue will be analysed further when we discuss the economic sphere.

Political choices - the "2000 Watt society" versus the "6 tonnes of $\mathrm{CO}_{2}$ society", Politicians should assume responsibility for societal choices with regard to GCC. Two of the options available are economic models focused on a low-carbon economy (6 tonnes of $\mathrm{CO}_{2}$ emissions per person per year, based on nuclear and renewable energies) and a resource-efficient solar one. If a combination of sufficiency and energy-saving strategies reduces the annual energy consumption to $2,000 \mathrm{~W}$ per capita, exploiting

\footnotetext{
${ }^{1}$ Neue Zürcher Zeitung (2008a).
} 
510

solar energy would suffice in many regions, ${ }^{2}$ as the solar energy hitting the Earth is about $2,000 \mathrm{~W}$ per square meter. Public research funds can then be focused in accordance with the chosen option, but there will be a difference in the economic competitiveness between the two options depending on the prices and availability of resources.

One problem with political decisions is that, once taken, they cannot be changed without a loss of face. Prof. Klaus Toepfer ${ }^{3}$ recently stated in a high-level meeting that the imposition of catalytic converters for automobiles (an end-of-pipe solution) had been the biggest mistake in his career. Yet they are still mandatory for all new cars.

\section{Ethics}

The Indian government is pursuing an ambitious plan to electrify all households by 2012. The supply-demand gap rather than the environmental issues drives most energy developments in India. The goal of maintaining high levels of economic growth also constitutes the most important driver of Chinese energy policy. 4

Global ethics should govern the consumption of non-renewable resources, both energy and materials, as was clearly stated in Chapter 8 of Agenda 21. As a result of Agenda 21, a dozen scientists in 1994 founded the Factor $10 \mathrm{Club}^{5}$ with the objective to develop strategies and metrics to reduce the resource consumption of industrial countries by 90 percent - a Factor of Ten. This concept of dematerialisation, which includes $\mathrm{CO}_{2}$ emissions, would bring all economies worldwide to an equal level of per capita resource consumption.

Applied to $\mathrm{CO}_{2}$ emissions, global ethics demand that industrial countries reduce their $\mathrm{CO}_{2}$ emissions to the present World average of 3.7 tonnes per annum per capita, while less developed countries (LDCs), such as India, can raise theirs to this world average (Figure 2). This would enable LDCs to enter the industrial revolution, to create wealth and escape poverty, as stated in the introduction to this section. The numbers in Figure 2 have been corrected for the "grey" $\mathrm{CO}_{2}$ embodied in the materials and goods that are imported and exported. However, the effects of world trade on all GHG emissions still have to be properly accounted for. ${ }^{6}$

${ }^{2}$ Prof Hans-Peter Dürr, former head of the Max Planck Institute for Astrophysics in Munich, has been promoting the $1.5 \mathrm{~kW}$ society for two decades through the Global Challenges Network, http:// www.gcn.de/. Professors at the ETH Zurich, the Swiss Federal Institute of Technology, promote a $2 \mathrm{~kW}$ society.

${ }^{3}$ Former German environment minister and former head of UNEP, the UN Environment Programme.

${ }^{4}$ Wilton Park Conference (2007, p. 3).

5 The Factor 10 Club's website is http://www.factor10-institute.org/.

${ }^{6}$ See for example: XIIIth International Conference on Input-Output Techniques, 21-25 August 2000, Macerata, Italy, and recent reports by the New Economics Foundation in London (Simms et al., 2007). 


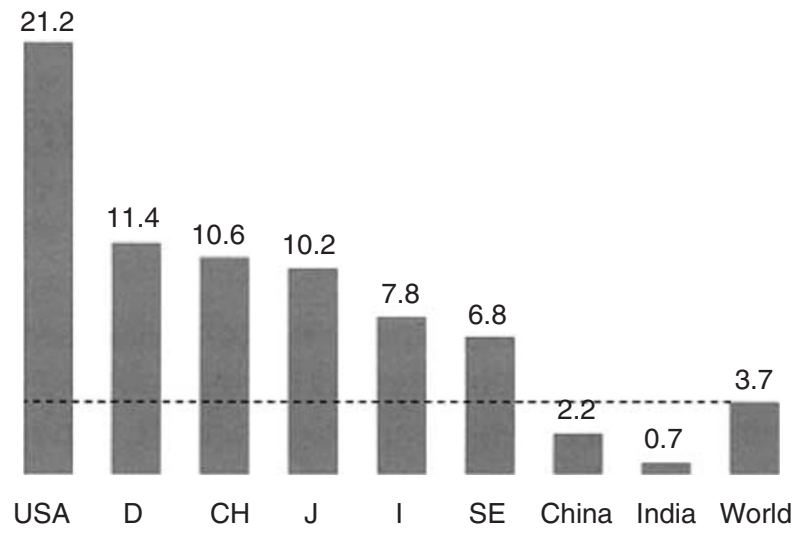

Figure 2. $\mathrm{CO}_{2}$ emissions in tonnes per capita per annum. Source: OECD Paris and BUWAL Bern.

\section{Media}

The media are part of the mist that prevails in the politics and ethics sphere, with the characteristic that "good news is no news". The fact that the famous "hockey stick" diagram showing the evolution of temperatures and $\mathrm{CO}_{2}$ concentrations in the atmosphere over the last hundred years was based on incorrect methodology, ${ }^{7}$ received a fraction of the attention that any doomsayer can count on. Similarly, a recent revision of data by NASA identified 1934 as the hottest year recorded in the U.S.A. during the last 100 years, followed by 1998, 1921, 2006 and 1931, and thus discredited the slowly rising temperature curve. It never made it into the media, and even NASA never published a news release but only posted the correction on its website. A media war has started on the issue of these unusually warm years in the 1920s, 1930s, which were only a few tenths of a degree Celsius away from the purportedly dangerous hot temperatures of the present. According to The Washington Times, only one thing is certain: "The political debate over global warming has rushed far ahead of the science". 8 But the media war completely misses the point that adaptation (of our behaviour) and prevention (of wastage) do make sense, independently of when the hottest years happened, and that "overall there has never been a better time to be alive. According to some, this is due to the fact that many journalists like to see themselves as questioning and sceptical, when the correct words would be cynical and negative". 9

Publications by economic actors directly concerned by GCC issues, such as major insurance and reinsurance companies, are generally ignored by the media if they do not predict Apocalypse now. ${ }^{10}$

\footnotetext{
${ }^{7}$ See for instance http://theclimatebet.com/ and http://en.wikipedia.org/wiki/Hockey_stick_controversy.

${ }^{8}$ The Washington Times (2007).

${ }^{9}$ Johnson (2008).

${ }^{10}$ CRO Forum (2006)
} 


\section{The ecology sphere}

Alexander von Humboldt defined climate as "the environmental space of all human experience and life: climate means all changes in the atmosphere affecting to some degree the human organs and senses". ${ }^{11}$

Johann Wolfgang von Goethe described climate as an "atmospheric space in which cultural, biologic, physical, social and geographic logic penetrate each other, without the possibility to reduce this complexity". ${ }^{12}$

Today, statistics and diagrams have replaced the holistic and cultural view of the past. Climate has become the result of statistical calculations in combination with change and anthropogenic focus.

Ecology is the science of nature as it is. "Ecologism"13 is a modern movement that defines nature as it should be; it is popular in Germany and has spread to other European countries. An early U.K. example dates from the 1970s, when snowfall brought British Rail (BR) to a standstill, despite earlier investments to make BR winter-proof. A manager of BR, called to explain the new breakdown of the railway system to the House of Commons, used the famous term that this had been "the wrong kind of snow".

Nature is a chaotic self-regulating system with no preference for hot, cold or moderate climates. Different micro-organisms thrive in the rain forests, in geysers or deserts by adapting to the local climate. If climatic conditions change, some species may benefit from the changed conditions, others may die out or move to a new, more convenient biotope. Wild animals in the Swiss mountains are multiplying through the absence of snow, as they are now more difficult to track and shoot. With rising temperatures, wild pigs are increasingly migrating from Sweden to Norway, leading to discussions of the pros and cons in Norway. Rising temperatures may also take a toll on human health: tropical diseases are spreading to higher latitudes in Europe and North America as the range of mosquitoes and the infections they carry are expanding rapidly.

Where ecology clashes with mankind, we speak of "natural disasters", not of "human misfortune": an avalanche in Antarctica is a non-event, but an avalanche that destroys a village or a road in the Alps is a "natural disaster" ${ }^{14}$ Independently of the reasons for GCC, adaptation and prevention measures make sustainable sense (in economic, ecological and social terms) in most countries where mankind clashes with nature.

The social failure of the "Commons" in the past centuries - the Tragedy of the Commons - should also be revisited in the ecology discussion, as the atmosphere, oceans, fish and biodiversity, even the global climate, are part of new global Commons.

\footnotetext{
${ }^{11}$ Humboldt (1858, reprinted 1997).

${ }^{12}$ Goethe (1779, reprinted 1946; 1825).

${ }^{13}$ A term first used by Michael Miersch at a conference organised by Avenir Suisse in Zurich, 12 January 2007.

${ }^{14}$ Stahel (1989).
} 
We cannot ignore the fact that world population has doubled since 1960, and that the disposable income per person has substantially increased; this has certainly led to higher world energy consumption and $\mathrm{CO}_{2}$ emissions. If we humbly accept that nature is chaotic and that any stability, according to Ilya Prigogine, announces havoc, the strategy with the highest success potential is to adapt our behaviour to nature, rather than to try to change it. This means developing flexibility, resilience and adaptation strategies to deal with uncertainty and to accept ecology as a dominant concept. Instead of fighting over who is responsible for GCC, or if it is real, we could accept it as an opportunity for innovation and prevention. The insurance sector and its risk engineering services could play a major role in such an adaptation strategy, in a true Public-Private Partnership (PPP).

Each hazard demands strategies adapted to local conditions and based on knowledge. Some strategies, such as climate-efficient buildings, exploit available knowledge, do not demand changes in our lifestyles and make sense independently of the question of whether the planet will warm up or cool down in the next hundred years. The American Council for an Energy-Efficient Economy, for one, will hold its 2008 summer study on this subject.

Measures to reduce the run-off speed of rain water, such as increasing the water absorption capacity of soil, are cost-efficient to mitigate the impact of flash floods after storms. But they demand a change in the way we are exploiting our land. The "sealing" of huge parts of the planet's surface with buildings and transport infrastructures, and the compacting of soils, need to be reduced. The use of horses instead of tractors in forest management greatly increases the water absorption capacity of forest soil and considerably reduces the run-off speed of surface water, for instance, but implies an adaptation by forest managers. Flood planes along brooks and rivers, and bridges that span rivers as well as flood planes, are a well-tested means to reduce floods, but restrict construction and housing opportunities. Regular maintenance and repair works on dams and jetties has always been more efficient than mandatory flood insurance. Construction techniques are available to mitigate the effects of windstorms on houses and roofs. Still different strategies would allow the reduction of the impact of wildfires but may restrict individual liberties.

Many impacts of GCC are the result of both natural and man-made factors, which vary between regions. Increasing droughts in Australia may be caused by a change from animal husbandry to water-intensive crops such as cotton and rice, more than by GCC. As the biggest changes in humidity and temperatures are expected for the polar and equator regions, general statements hardly make any sense. ${ }^{15}$

Similarly, the increase in mudslides and erosion in mountain areas is due to changes in both land use and micro-climates, according to research at Basel University: warmer temperatures allow for a longer and more intensive agricultural exploitation of land. A more sustainable use of the land, taking into account possible changes in climatic conditions, could stabilise the situation. ${ }^{16}$

\footnotetext{
15 See Baettig et al. (2007).

${ }^{16}$ Study summarised in Neue Zürcher Zeitung (2007a, p. 13).
} 
An intelligent dialogue with ecology also offers new economic opportunities. A September $2005 \mathrm{EU}$ conference looked into new perspectives of the knowledge-based bio-economy that can transform life sciences knowledge into new, sustainable, ecoefficient and competitive products. ${ }^{17}$ The long-term benefits of such a bio-economy would be obvious for rural development and sustainability, and would serve to underwrite the competitiveness of the European agriculture, food and chemical industries.

\section{The ecological footprint}

The ecological footprint is a metric to assess the carrying capacity of the Earth, by computing the land surface that would be necessary to support human life on the Earth, and compare it to the natural capacity available. In 2003, the surface necessary to support the needs for food, clothing, energy and living space of each person corresponded to 21.9 ha of surface, but the biological capacity of the Earth is only 15.7 ha par person. Mankind is thus already following an unnatural path of development with regard to the carrying capacity of the Earth. ${ }^{18}$

Initiatives to increase the available ecological surface through smart autarky, such as soil-less (hydro) agricultural plantations and, in the vertical dimension, multi-storey vegetable and flower production, are only in their infant stage.

Some "green" initiatives, such as biofuel production and $\mathrm{CO}_{2}$ compensation schemes, increase the ecological footprint despite the fact that they are "climatefriendly". Furthermore, these initiatives ignore issues such as potential water shortages (agriculture is already responsible for 75 percent of water consumption) versus sufficient drinking water supplies (for instance Barcelona) and protected fish populations, and the fight between land use for food, feedstuff, biofuels and biodiversity. ${ }^{19}$

\section{The global science sphere}

There is general agreement today in the scientific discussion of the evolution of GCC in the past. Several long-term cycles have been identified for $\mathrm{CO}_{2}$ level, mean sea level and average temperature, by analysing ice cores from drilling in Greenland and Antarctica. The cycles have different volatilities and cycle times; some may be correlated with or triggered by other cycles, such as the solar cycle. GCC is thus an extremely complex system without a manager or master plan.

The global climate is influenced by many factors, themselves submitted to changes. They include the concentration of gases in the atmosphere and the oceans, solar cycles

\footnotetext{
17 "The knowledge-based bio-economy, transforming life sciences knowledge into new, sustainable, ecoefficient and competitive products", conference report available at http://ec.europa.eu/research/ conferences $/ 2005 / \mathrm{kbb} /$ report_en.html.

$18 \mathrm{http}: / /$ www.footprintnetwork.org/gfn_sub.php?content = footprint_overview.

${ }^{19}$ In early 2008, Californian farmers had to reduce their water consumption - and the surface of irrigated fields - by 30 percent; in Neue Zürcher Zeitung (2008b, p.7).
} 
that impact the orbit of the Earth and the intensity of solar energy received on the Earth, ${ }^{20}$ elements from outer space hitting the Earth, the magnetic fields of our planet, as well as ocean currents and atmospheric jet streams. ${ }^{21}$

On a micro-level, $\mathrm{CO}_{2}$ absorption and emission by plants and oceans, absorption and reflection of solar light by soil, forests and water surfaces are some of the major factors of GCC. Higher $\mathrm{CO}_{2}$ concentrations in the atmosphere could change the transpiration of plants and lead to a higher run-off of rainwater. ${ }^{22}$ Transpiration means that while the plants breathe in $\mathrm{CO}_{2}$, they simultaneously emit water vapour. In an atmosphere that is rich with $\mathrm{CO}_{2}$, plants breathe faster, and more water remains in the soil. This phenomenon could partly explain the increased run-off into the oceans observed in Europe since $1990 .^{23}$

A general agreement in the scientific discussion may be possible for the long-term future. The problem then is the short-term future (in geologic terms), that is, the coming hundred years. The IPCC in its reports has singled out $\mathrm{CO}_{2}$ emissions as the major issue influencing GCC, and rising sea level as the dominating threat to mankind in the 21 st century. ${ }^{24}$ But there are a number of hitches.

Nehru, the first Prime Minister of India, fought the traditional dominating belief in India that science is cultural. He insisted that science is independent of religion and that there is only one science for Hindus, Muslims and Christians. In GCC discussions, cultural differences on risk perception between Europe, Asia and America play again a substantial role; witness the acceptance or refusal of nuclear energy as a low-carbon option.

Progress in science is not the result of a democratic process, but of a series of new insights of brilliant minds that discover new truths and some principles of scientific rigour. ${ }^{25}$ The relativity theory of Albert Einstein, published in 1905, was a publication that contradicted the scientific wisdom of the time but did not have to go through a peer-review process. There are serious doubts about whether its publication would be possible today, when all scientific publications are subject to peer-review to eliminate "weird" ideas.

According to French scientist Pascal, science is a balloon of knowledge surrounded by the universe of the unknown. If the volume of the balloon increases, the contact with the unknown increases much faster than the knowledge inside the balloon. The IPCC approach relies on the belief that more data will reduce uncertainty. Politics might well be the loser of GCC, if new scientific results contradict existing truths.

According to a principle promoted by Sir Karl Popper, attempts have to be made periodically to falsify existing truths as a method of verification. Another principle of science is that any theory and its interpretation is published together with the tools that have been used - methods, software, metrics, data - to enable other scientists to

\footnotetext{
${ }^{20}$ These issues are known as Milankovitch cycles.

${ }^{21}$ See for instance www.ozean-klima.de.

22 Betts et al. (2007).

${ }^{23}$ Gedney et al. (2006).

${ }^{24}$ www.ipcc.ch, http://www.un.org/climatechange/index.shtml, and www.pik-potsdam.de.

${ }^{25}$ See for instance Allègre (2007).
} 
verify and reproduce the results. But many of the GCC models are of proprietary nature and do not allow for verification.

The IPCC attempts to understand and master this complex and chaotic body of knowledge. It consists of 600 invited experts, mostly physicists and meteorologists. The opinions of the individual scientists are submitted to a vote to identify the dominating one. The political delegations from the member states then decide which parts of the scientific documents go into the IPCC report (IP stands for Intergovernmental Panel). A grass-roots movement of experts regards the resulting reports as a political document, ${ }^{26}$ questioning whether the principle of "science at arm's length" is being applied (similar to the principle of transactions at arm's length in business). ${ }^{27}$

An indication supporting this argument is the recommendation in the latest IPCC reports to increase the production of biofuels. This might reduce $\mathrm{CO}_{2}$ emissions, but it increases the ecological footprint and certainly does not fulfil the need for a holistic approach, which is at the base of sustainable development. The first visible results of the political promotion of biofuel production may be visible as rising food prices lead to financial speculation, social problems and even public revolts on global level.

A comparison with other intergovernmental organisations, such as $\mathrm{CERN}^{28}$ in Geneva, might provide useful insights. CERN is managed by scientists, including several Nobel Prize winners in physics, who also supervise the scientific reporting. Intergovernmental vehicles, such as IPCC and CERN, are a political attempt to overcome the resistance of nation states to take a leadership role, or to fund basic research. The structure and independence of these vehicles differ and are underresearched.

\section{The technology and competitiveness sphere}

As in science, progress in technology is not the result of a democratic process, but of a series of new insights of brilliant minds that discover new solutions.

The $\mathrm{CO}_{2}$ discussion primarily concerns the industrialised economies, which emit 80 percent of all $\mathrm{CO}_{2}$. Their economic actors thus should have an incentive to innovate and their politicians an incentive to adapt framework conditions. If economic actors of the industrialised countries do not jump into action, they leave an opportunity for industrialising economies to leapfrog them. This does not only apply to energy and $\mathrm{CO}_{2}$; there are water-efficient methods, such as drip irrigation developed by Israel in greening the Sinai desert, that use a quarter of the water of traditional irrigation.

Now, if we accept that $\mathrm{CO}_{2}$ is the main trigger of $\mathrm{GCC}$, there are a number of options to reduce or prevent $\mathrm{CO}_{2}$ emissions, which are summarised in Table 1 . However, it is important to keep in mind that the commercialisation of some of these

\footnotetext{
${ }^{26}$ See for instance http://node-O.mneisen.org/2007/03/13/die-klima-inquisition.

${ }^{27}$ A number of German experts disagreeing with the IPCC report are quoted in Die Welt (2008, p. 9).

${ }^{28}$ CERN, Centre Européen de Recherche Nucléaire, or European Organisation for Nuclear Research, http://public.web.cern.ch/Public/Welcome.html.
} 
Table 1 Three ways to reduce $\mathrm{CO}_{2}$ emissions

\begin{tabular}{|c|c|c|c|c|}
\hline Energy use & (1) Sufficiency & $\begin{array}{l}\text { (2a) Transport, } \\
\text { heating and } \\
\text { cooling }\end{array}$ & $(2 b)$ & $\begin{array}{l}\text { (3) Process } \\
\text { energy }\end{array}$ \\
\hline $\mathrm{CO}_{2}$ reduction & $\begin{array}{l}\text { Prevention of } \\
\mathrm{CO}_{2} \text { emissions }\end{array}$ & $\begin{array}{l}\text { Lower dissipative } \\
\mathrm{CO}_{2} \text { emissions }\end{array}$ & $\begin{array}{l}\text { Zero or low } \\
\text { carbon }\end{array}$ & $\begin{array}{l}\text { Preservation of } \\
\text { embodied } \mathrm{CO}_{2}\end{array}$ \\
\hline Strategy focus & Knowledge & $\begin{array}{l}\text { Intelligent use of } \\
\text { technology }\end{array}$ & $\begin{array}{l}\text { New (green) } \\
\text { technologies }\end{array}$ & $\begin{array}{l}\text { Management of } \\
\text { physical assets }\end{array}$ \\
\hline
\end{tabular}

solutions may be slow in industrialised countries as they clash with locked-in technologies and stranded capital in the economic sphere.

(1) Sufficiency is a generic solution to reduce $\mathrm{CO}_{2}$ emissions, for instance by preventing technical disasters, which are often linked to fire and thus environmental impairments. Prevention uses the knowledge accumulated, for instance, in universities, research centres and risk engineering, and is application-focused. To justify prevention economically, it is often necessary to know the total cost of the expected loss, the "Iceberg".

(2) Transport and heating and cooling produce "dissipative" $\mathrm{CO}_{2}$ emissions that can be reduced by intelligent uses of technology, or low-carbon solutions:

(a) the use of best available technology (BAT), such as combined heat and power production (CHP) in buildings, demand-driven electric pumps and motors (a 20-year-old battle horse of Amory Lovins ${ }^{29}$ ); energy-efficient lighting technologies in public lighting systems, such as white LED and plasmonenhanced photonics;

(b) zero or low-carbon technologies, such as low-temperature/low-pressure processes, for example to wash clothes at ambient temperature with detergents using enzymes from cold regions; ${ }^{30}$ renewable energies such as geothermal heat, solar, hydro, wave and wind energy; wastes (biomass, cooking oil) turned into energy, and nuclear and hydrogen energy. ${ }^{31}$

(3) Preserving embodied $\mathrm{CO}_{2}$ emissions from processes, captured in materials and durable goods (grey energy) by the management of physical assets over time through new business models focused on product-life extension activities (reuse, repair, remanufacturing, technologic updating) of buildings and infrastructures, equipment and durable goods, further explained in the next section on the economic sphere.

The technology sphere is a key to improving applications of "dissipative" $\mathrm{CO}_{2}$ (see number 2 above) from transport, space heating and cooling. Innovations to explore

\footnotetext{
${ }^{29}$ Amory B. Lovins, Chairman of the Rocky Mountain Institute, Snowmass, CO.

${ }^{30}$ See for instance www.kalt-aktiv.de by Procter \& Gamble.

${ }^{31}$ See for instance Rifkin (2002).
} 
new avenues, such as converting dirty energy into clean energy - gas to liquid, coal to liquid, direct coal liquefaction and carbon separation and sequestration - are still under development or have to prove their economic feasibility on an industrial level.

What is clear is that a judgement on the sustainability of different technologies must be based on the overall pollution balance and resource efficiency in a life-cycle perspective. Diesel engines may burn less "oil" and thus produce less $\mathrm{CO}_{2}$ emissions than gasoline engines, but even the latest diesel technology emits five times more $\mathrm{NO}_{x}$ than a gasoline engine. ${ }^{32}$ And many biofuels (bioethanol or biodiesel) have an overall negative ecological balance compared to gasoline.

Zero and low-carbon technologies are often subject to a clash of cultures. Witness nuclear energy, which is seen by some as a solution, by others as devil's work. Of the 439 nuclear power plants in operation today, 104 are in the U.S.A., 59 in France, 55 in Japan, and 31 in the Russian Federation. Between 15 and 20 each are situated in South Korea, the U.K., Canada, Germany, India and Ukraine. According to Ulrich Beck's theory of the Risk Society, everybody might suffer through nuclear accidents, but only few will profit from producing nuclear electricity. The latest development is Russia's mobile nuclear power stations, which are integrated into sea-going vessels and use the reactor technology of Russian nuclear submarines to produce electricity on-site, where it is needed.

Overall resource efficiency is neglected in the present $\mathrm{CO}_{2}$ discussion, be it (nuclear) power stations or (hybrid) vehicles. Cars with low $\mathrm{CO}_{2}$ emissions over the full productlife are the challenge, not lower $\mathrm{CO}_{2}$ emissions in use; and the lower the energy consumption in use, the higher the relative part of the energy in production and endof-life activities.

Low-carbon vehicles are in commercial use in a number of countries. Compressed natural gas (CNG) for vehicles is widely used in Pakistan, India, Italy and Japan, but little in Germany or the U.S.A. A successful introduction of these technologies into new markets thus depends on commercial innovations, such as new distribution systems, rather than new technology.

The first hybrid car built by Ferdinand Porsche in 1900 was an electric car with a small combustion engine to recharge the battery. This concept is now being picked up again by emerging car manufacturers without stranded capital, such as Mindset, a Swiss company. Electric vehicles are less resource-intensive (they are "dematerialized"): small electric motors are integrated into some wheels and receive the electricity from a central unit; there is no gearbox or clutch. Electric cars have a battery as a central storage unit, which needs to be recharged frequently (plug-in electric cars). The Tesla $^{33}$ is a high-tech example of this technology. Electric vehicles (and modern elevators) generate electricity to recharge the batteries in braking; trains and tramways use the grid through an overhead wire instead of a battery.

\footnotetext{
${ }^{32}$ Prof. Roland Clift, CBE, University of Surrey, has drawn my attention to the fact that $\mathrm{N}_{2} \mathrm{O}$, not $\mathrm{NO}_{x}$, is a major GHG. The principal impacts of $\mathrm{NO}_{x}$ are local or regional - formation of tropospheric ozone, nitrate aerosols and acid deposition - rather than global. So this argument is actually more multi-layered than presented and involves trade-offs between global and local impacts.

${ }^{33}$ Tesla Motors, situated in Silicon Valley, top speed $220 \mathrm{~km} / \mathrm{h}$, accelerates in 4 seconds from 0 to $100 \mathrm{~km} / \mathrm{h}$.
} 


\section{Hydrogen}

Hydrogen vehicles are similar to electric ones, except that the central unit is not a battery but a "hydrogen tank" and a fuel cell to transform hydrogen into electricity. This design has been used for the car with the lowest fuel consumption on record, achieving $5,500 \mathrm{~km}$ with the equivalent of one litre of gasoline. ${ }^{34}$

Hydrogen is already used in a number of applications, such as a new class of German submarine ${ }^{35}$ and stationary applications, and is at the heart of projects close to realisation, such as California's hydrogen highway, ${ }^{36}$ the future mass-produced Chinese fuel cell car, and the Hydrogen and Fuel Cell Demonstration Project by Japan's METI. ${ }^{37}$

The hydrogen fuel-cell propelled German Alpha submarines U212 combine the hydrogen for the ship with the oxygen for the crew. This enables the submarine to stay submerged for much longer periods than any diesel-powered competitor. The Italian utility company ENEL has started building a 12-megawatt power station that uses a hydrogen-powered gas turbine in Porto Marghera near Venice, one of the first worldwide. The plant is part of a "Hydrogen Park" and uses hydrogen produced as by-product (waste) in petrochemical processes.

The California hydrogen highway is a system design comprising both vehicles and a functioning refuelling infrastructure. It is pushed by Governor Schwarzenegger and thus less hindered by adverse political framework conditions. A Chinese hydrogen fuel-cell car was developed by a research team directed by Prof. Wan Gang, then president of Tongji University Shanghai and since May 2007 Minister of Technology and Innovation of the People's Republic of China. It should be on the world market in 2009 with few political obstacles.

Innovative distribution systems are the key to the utilization of hydrogen-based road transport systems at early stages. In Japan, two corporations decided to start with small mobile basic supply stations, before expanding the hydrogen supply network step by step in each area in response to demand. In April 2007, the two Japanese companies ${ }^{38}$ announced that they had developed mobile refuelling stations for liquefied hydrogen mounted on semi-trailers, and started to provide an initial hydrogen supply infrastructure at satellite stations set up by the Japan Hydrogen and Fuel Cell Demonstration Project under METI.

\section{The economic sphere}

The fact that GCC is caused by the industrial countries of this world is correct, that it will hit the poor people more than the rich may be economically wrong, as most petrochemical refineries, many nuclear power stations and transport infrastructures in

\footnotetext{
${ }^{34}$ Paccar 2, developed by ETH Zürich, Shell eco-competition 2006.

${ }^{35}$ See NZZ (2007b).

${ }^{36}$ http://www.hydrogenhighway.ca.gov/; http://www.hydrogensociety.net/; http://www.h2.ca/.

${ }^{37}$ Ministry of Economy, Technology and Industry.

${ }^{38}$ Iwatani International Corporation, a Japanese company in the natural gas and energy business, together with Kansai Electric Power Company.
} 


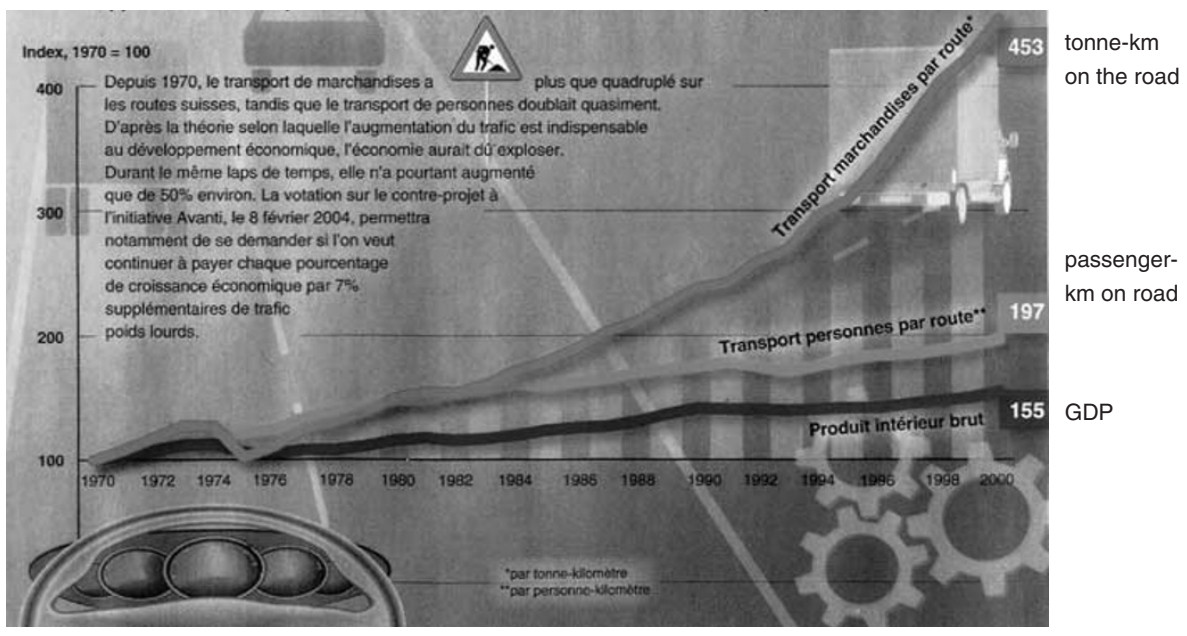

Figure 3. Relative growth of GDP, road transports of goods (in tonne-km) and of people (in passengerkm), 1970-2000, Switzerland, 1970=100 per cent. Source: Swiss Federal Statistics Office Bern.

the world are situated only slightly above - or even below - sea level, such as Amsterdam's Schipol airport.

\section{Macro-economy}

The issues at stake that will be analysed here are the link between $\mathrm{CO}_{2}$ emissions and GDP; the impact on the economy of preventing $\mathrm{CO}_{2}$ emissions; and the prevention of $\mathrm{CO}_{2}$ emissions and waste through the management of physical assets.

\section{The link between $\mathrm{CO}_{2}$ emissions and GDP}

On a global level, the GCC discussion primarily concerns the industrialised economies, which are emitting 80 per cent of all $\mathrm{CO}_{2}$ and the ethical issues raised earlier in this paper. World trade in the global "Bazaar Economy" 39 amplifies $\mathrm{CO}_{2}$ emissions: since 1950 exports have risen by 6.2 percent per annum, while production has only increased by 3.8 percent per year. The globalisation of the economy logically leads to longer transport routes, higher transport volumes and higher energy consumption in transport and refrigeration. A shift away from global manufacturing to a knowledge or functional service economy, ${ }^{40}$ on the other hand, corresponds to a regionalisation of the economy, reducing the transport intensity of the economy and the $\mathrm{CO}_{2}$ emissions per unit of GDP.

On a national level, the imbalance between $\mathrm{CO}_{2}$ and GDP is more accentuated for mature industrialised countries. Figure 3 shows the relevant data for Switzerland: from 1970 to 2000, goods transport increased faster than GDP. Today, each additional percentage point of GDP causes a 7 percent increase in goods transported on the road.

\footnotetext{
${ }^{39}$ Developed by Prof Hans-Werner Sinn, head of the ifo Institute in Munich, Germany.

${ }^{40}$ Stahel (1997a).
} 
This development is unsustainable; a radical change of course is thus necessary to achieve wealth with less resource consumption.

\section{The impact of the prevention of $\mathrm{CO}_{2}$ emissions on the economy}

A comparison with the waste policies of the 1990s raises doubts as to whether the economic framework conditions will change rapidly. If one replaces "waste" in the waste prevention publications of the 1990 s by " $\mathrm{CO}_{2}$ emissions", one would expect to get easy recipes for success; however, such a comparison could indicate why policies to prevent energy wastage would fail.

The (publicly financed) waste research of the 1990s has taught us several lessons, which will sound quite familiar to most risk managers, but are ignored by today's politicians:

- end-of-pipe solutions are economically inefficient (in risk management terms: prevention is cheaper than cure);

- waste prevention has to be economic priority number one (loss prevention eliminates the invisible part of the cost iceberg);

- waste-free solutions have to be designed into products (risk management is not an additional coat of paint).

What is the track record of the 1990s' waste prevention policies? They were never implemented, but few governments have given the reason why. An exception is the Swiss Parliament, which has stated that "effective measures to prevent waste could change or even reduce the consumption of goods. This in turn could have negative effects on economic growth, which is considered unacceptable and politically undesired. End-of-pipe waste strategies (such as recycling and waste incineration) are considered more acceptable". ${ }^{41}$

But is the economic truism that prevention is bad for growth - be it $\mathrm{CO}_{2}$ emissions from energy consumption or consumer waste - correct? The answer is in the eye of the beholder: in an industrial throughput economy, the success of which is "flow", it may seem true. In a sustainable economy based on "stock" it is plainly wrong. ${ }^{42}$

Radical reductions of $\mathrm{CO}_{2}$ emissions imply a structural change in the economy, from flow to stock optimisation, from manufacturing to a functional service economy. ${ }^{43} \mathrm{CO}_{2}$ credits should be given for any reduction of either the flow (throughput) of emissions or prevention measures safeguarding the embedded $\mathrm{CO}_{2}$ stock in existing physical assets in order to create a level playing field.

The success of the industrial throughput economy is measured in flow and production optimisation; the success of the service economy is based on wealth (stock)

\footnotetext{
${ }^{41}$ BHP-Hanser und Partner (2005). "Wirkungsvolle Massnahmen zur Vermeidung von Siedlungsabfällen hätten Veränderungen oder gar eine Verminderung des Güterkonsums zur Folge. Wegen der befürchteten dämpfenden Wirkungen auf das Wirtschaftswachstum und einer allfälligen Beeinträchtigung der Handels- und Gewerbefreiheit wurden derartige Massnahmen in der politischen Diskussion als unverhältmässig eingestuft und nicht weiter verfolgt. Abfallverwertung und umweltverträgliche Behandlung und Ablagerung der verbleibenden Abfälle werden als erfolgversprechend weiterverfolgt".

42 Giarini and Stahel (1989).

${ }^{43}$ Stahel (1997b).
} 
management in a knowledge-based society. Decoupling economic success from resource consumption is counterintuitive in the industrial, but a key to success in the service economy. ${ }^{44}$

The prevention of $\mathrm{CO}_{2}$ emissions and waste through the management of physical assets Lowering $\mathrm{CO}_{2}$ emissions by managing the existing physical assets (stock) is possible, as exemplified by the remanufacturing of the first generation of German high-speed trains $^{45}$ (named ICE 1 redesign). Since their commissioning in 1990, the 59 ICE 1 trains have operated for 15 years and done 15 million kilometres each. The remanufacturing to a condition "better than new" in 2006-2008 has made them fit for a second life of 15 years: the redesign upgraded the trains to new user needs, increased their passenger capacity and upgraded the railway-relevant technologies. It also created new skills and capabilities at the workshops involved.

Economically, the redesign cost $€ 3$ million per train, dwarfing procurement costs of $€ 25$ million for a new train; in addition, it saved $€ 1$ million of social costs on a global level, according to the indications of the Stern report. ${ }^{46}$ But industrial economists would argue that the redesign reduced German GDP by $€ 1.3$ billion (see the argument of the Swiss Parliament above).

In terms of ecology, the redesign directly saved 80 percent of the trains' materials and embodied energy, amounting to 16,500 tonnes of steel and 1,180 tonnes of copper, and prevented 35,000 tonnes of $\mathrm{CO}_{2}$ emissions ${ }^{47}$ as well as 500,000 tonnes of mining wastes ("rucksacks"). Further reductions in $\mathrm{CO}_{2}$ emissions come from avoided transport energy in the value chain, as remanufacturing is a local activity.

Despite this impressive prevention of $\mathrm{CO}_{2}$ emissions, no credit for tradable $\mathrm{CO}_{2}$ rights was given under the Kyoto Agreement. However, if the German Railways had financed the remanufacturing of trains in, for example, Africa under a clean development mechanism (CDM) contract, it would have been credited with 35,000 tonnes of $\mathrm{CO}_{2}$ emission rights, worth about $€ 350,000$.

Accepting that $\mathrm{CO}_{2}$ is the main trigger of climate change, politics should apply nonapartheid policies in the prevention of $\mathrm{CO}_{2}$ emissions: remanufacturing services safeguarding the $\mathrm{CO}_{2}$ stock of embodied energy should be rewarded as equally as reductions of $\mathrm{CO}_{2}$ emissions in manufacturing and production.

\section{Micro-economy}

The corporate experience of the late 20th century has taught us that zero-fault manufacturing and loss and pollution prevention make economic and ecological sense. In manufacturing processes, waste prevention means turning 100 percent of resources

\footnotetext{
${ }^{44}$ Stahel (2006).

${ }^{45}$ ICE 1 Redesign, a case study by The Product-Life Institute Geneva, http://product-life.org.

46 HM Treasury (2007).

${ }^{47}$ By comparison: the one-thousandth registration approved on 14 April 2008 under the UNGCC's CDM scheme was an energy efficiency project in Andhra Pradesh, India, expected to generate a carbon dioxide reduction of around 34,000 tonnes.
} 
into 100 percent of goods, thus reducing costs and increasing competitiveness. The GE Six Sigma principles and the Polluter-Pays-Principle are witnesses of this period.

Economic actors are driven by competitiveness and by cost imperatives. In the face of rising resource costs, higher resource productivity (more with less) means higher competitiveness in manufacturing!

Corporations therefore reduce their own energy consumption and $\mathrm{CO}_{2}$ emissions, as well as those of their products, for competitiveness reasons. Manufacturing corporations have started using $\mathrm{CO}_{2}$ arguments in their corporate strategies, buildings and the design of their products. Taking United Technologies (UTC) as an example, energy consumption is down 19 percent since 1997 for a company that has doubled its revenue. One of its innovative products is large fuel cells that convert up to 90 percent of primary energy into usable energy, compared to 38 percent in a conventional power plant. But even such traditional products as elevators can be improved: UTC's Gen2 elevators with regenerative drives give back the energy on descent. And UTC's new HQ building will be a net energy producer.

Similarly, for actors of the service economy, such as banks and insurance companies, saving energy means lower operating costs. Video conferences instead of long-distance air travel save time, costs and $\mathrm{CO}_{2}$ emissions; office buildings designed as net producers of energy are signs of good corporate citizenship; and directing assets and investments towards resource-efficient corporations are win-win situations for economic and ecological reasons.

\section{Insurance}

Insurance can influence anthropogenic GCC on the investment side, the underwriting side and in daily operations. Many possible scenarios on the underwriting side have been described over a number of publications in the last months.

Investments may be most affected by changes in the economy due to rising resource prices, both energy and materials. Economic actors of the throughput-focused industrial economy (e.g. cement and steel mills) may be more heavily hit than managers of physical assets (e.g. facility managers of parking lots or office buildings) or actors of the knowledge economy. Insurers can protect themselves through a preference for resource-efficient corporations, therefore commercialising products with a high value-per-weight ratio. ${ }^{48}$

On the underwriting side, a possible increase in potential hazards from GCC affecting the insurance industry could come from weather-related events, such as storms, floods, mudslides, but also related liability issues. Positive impacts on underwriting can stem from the absence of losses due to avalanches and ice falls (such as the Mattmark disaster in Switzerland on 30 August 1965), and new opportunities in markets created by GCC such as the agricultural and industrial development of northern regions including Siberia.

GCC might also affect crop insurance (water shortage in the U.S. West and the Mediterranean, combined with new pests), health insurance (tropical diseases

\footnotetext{
${ }^{48}$ See Stahel (2006).
} 
The Geneva Papers on Risk and Insurance - Issues and Practice

524

Table 2 Three ways for insurance companies to reduce $\mathrm{CO}_{2}$ emissions

\begin{tabular}{|c|c|c|c|c|}
\hline $\begin{array}{l}\text { Type of energy } \\
\text { use }\end{array}$ & (1) Sufficiency & $\begin{array}{l}\text { (2a) Transport, } \\
\text { heating and } \\
\text { cooling }\end{array}$ & $(2 b)$ & (3) Process energy \\
\hline $\mathrm{CO}_{2}$ reduction & $\begin{array}{l}\text { Prevention of } \mathrm{CO}_{2} \\
\text { emissions }\end{array}$ & $\begin{array}{l}\text { Lower dissipative } \\
\mathrm{CO}_{2} \text { emissions }\end{array}$ & $\begin{array}{l}\text { Zero or low } \\
\text { carbon tech }\end{array}$ & $\begin{array}{l}\text { Preservation of } \\
\text { embodied } \mathrm{CO}_{2}\end{array}$ \\
\hline Strategy focus & $\begin{array}{l}\text { Insurers selling } \\
\text { knowledge, e.g. risk } \\
\text { engineering services }\end{array}$ & $\begin{array}{l}\text { Adapting } \\
\text { insurers' assets to } \\
\text { intelligent } \\
\text { technologies }\end{array}$ & $\begin{array}{l}\text { Investing in } \\
\text { technology } \\
\text { champions }\end{array}$ & $\begin{array}{l}\text { An active management } \\
\text { of insurers' physical } \\
\text { assets }\end{array}$ \\
\hline
\end{tabular}

spreading north) and construction insurance (termites invading new regions, forest fires destroying human settlements due to a lack of water).

Measures to reduce $\mathrm{CO}_{2}$ emissions may lead to new hazards. Zero-energy houses often have minimal ventilation causing high indoor moisture levels, fungus problems and an increase in people suffering from multiple chemical symptoms. Wood stoves could increase the fire risk in apartments. Furthermore, a focus on $\mathrm{CO}_{2}$ emission reductions by architects and engineers may lead to a neglect of other issues, such as higher wind and storm attacks on existing bridges and buildings, and the proper maintenance of these structures.

Furthermore, today's public safety levels are often achieved with permanent lighting and closed circuit television. This concerns public spaces at night, but also underground transport installations (subway stations, motorway tunnels, underground car parks, bank vaults, museums). A reduction of lighting levels may attract vandals and criminals, or lead people to shun public transport for private cars, with negative consequences for insurance and $\mathrm{CO}_{2}$ emissions.

On a systemic level, business interruption insurance could be affected. Pressure to reduce $\mathrm{CO}_{2}$ emissions, or taxes on $\mathrm{CO}_{2}$ emissions, starts to affect the construction of new power stations. This reduces the resilience of the electricity grid to surges in demand, and can lead to a breakdown of the economy, as was the case in February 2008 in South Africa, where mines had to shut down. If hospitals are affected, the health service will suffer and the mortality rate may go up. The "normal" reaction of businesses to this is the procurement of diesel generators, which is already the case in many LDCs - with a resulting inefficiency in power generation and an increase in GHG emissions.

The increase in green power (solar PV and wind power) that feeds into the electricity grid has a similar effect. This corresponds to a regionalisation of electricity production without any redundancy. It might lead to a reluctance of the grid operators to provide auxiliary power stations for winter times when demand is high and supply is low due to storms (no power from windmills) and absence of sun. The principle of "think the unthinkable" enables an assessment of potential claims for insurers (Table 2).

(1) The risk engineering services of major insurance and re-insurance companies are pools of knowledge to identify and define sufficiency solutions to reduce $\mathrm{CO}_{2}$ emissions through loss prevention. 
(2) Transport, heating and cooling produce "dissipative" $\mathrm{CO}_{2}$ emissions that can be reduced by intelligent uses of technology or investments in low-carbon solutions:

(a) most insurance companies own a considerable volume of real estate that can be adapted to the BAT, such as CHP in buildings; demand-driven electric pumps and motors; energy efficient lighting technologies; water-cooled computer servers. Similarly, vehicle fleets can be converted to BAT, such as CNG or hydrogen, or replaced by sufficiency strategies or shared means of transport;

(b) investments in companies producing zero or low-carbon technologies, such as bio-technology to replace traditional chemistry in production processes; renewable energies such as geothermal heat, solar, hydro, wave and wind energy, biomass wastes turned into energy, and nuclear and hydrogen energy.

(3) Preserving embodied $\mathrm{CO}_{2}$ emissions from processes, which are captured in materials and durable goods, such as buildings, equipment, vehicles. They can be preserved by the management of physical assets owned by insurance companies based on a life-cycle-analysis approach. Service-life extension instead of procurement of replacement goods has a huge untapped potential to reduce $\mathrm{CO}_{2}$ emissions (see the example of the German ICE1).

\section{Consumers}

With regard to innovation, consumers have the role of selection; ${ }^{49}$ this is also true for innovations to reduce $\mathrm{CO}_{2}$ emissions. Consumers can only choose among the goods and services offered in the market; the supply-side is influenced by international competition and the framework conditions of politics as much as by demand.

But consumers also have the choice of sufficiency, such as switching from cars to public transport or bicycles for short distance transport; repairing goods instead of replacing them; driving smaller cars; growing their own vegetables, and living in zero energy houses. Yet many of these choices will not only reduce $\mathrm{CO}_{2}$ emissions but also GDP.

\section{Summary and conclusions}

It's like subprime mortgages ... one of longest-kept secrets of uncalculated risk. By not acting on climate change ... we face the same kind of [risks] with what we're seeing in subprime. ${ }^{50}$

This paper has shown that the issue of GCC is reflected in several issues or spheres: ethics, ecology, science, technology and economy. Each sphere has its own agenda:

- the key to solving the ethics issue are the industrialised countries, which consume 80 percent of all resources and emit 80 percent of anthropogenic GHG including $\mathrm{CO}_{2}$;

\footnotetext{
${ }^{49}$ Giarini and Stahel (1989).

${ }^{50}$ Mindy Lubber, President of Ceres.
} 
- one key to the ecology issue is the ecological footprint, which expresses the overexploitation of the planet Earth, mostly by rich countries (such as overfishing) and partly by poor countries (such as overgrazing, deforestation);

- the key to the science issue may be for mankind to accept nature as a chaotic system governed by long-term cycles, manageable by an adaptation to uncertainty as the guiding principle;

- the key to technology may be accepting that innovation, another chaotic system, will continue to propose new solutions, which will change the factors at the root of the man-made part of GCC - and applying BAT could already have a big impact;

- the key to the economic issue is the fact that the industrial economy is optimal for developing countries; and that the management of physical assets is the key for industrialised countries to become rapidly more resource efficient, with regard to both energy and materials.

Other major issues, such as the doubling of the world population over the last 50 years and the rise of disposal per capita income, and their impact on GCC, have not been included. However, their inclusion would not have changed the fundamental characteristics of complex systems: they cannot be optimised by the optimisation of any of their individual parts, or by a focus on a single factor. Hints for solutions will come from a system optimisation approach and a better understanding of underlying principles.

The similarities between GCC and the sub-prime crisis may be far greater than anticipated by Mindy Lubber: confidence in the models used and the reputation of those involved is a casualty in both cases. "Alan Greenspan observed that these (financial) models were not complex enough to capture reality. But his comment could be mistaken to imply that if only the models were more complex still, then future disasters might be averted. But in times of complexity, common sense must prevail". 51

Sustainability (and financial investment) is a holistic concept of economic, ecological and social optimisation, of which $\mathrm{CO}_{2}$ emissions are a tiny part. A single focus can easily unbalance the system - witness the unfolding food versus biofuel case, or increase in resource consumption caused by the growth of green power production (solar, wind, wave energy). And in some cases, such as in health issues and the waste water treatment of large cities, it neglects the fact that ecological progress and a higher sustainability are only achievable with increased energy consumption and higher GHG emissions.

It might well turn out that barking up the $\mathrm{CO}_{2}$ emission tree distracted public attention from the looming (drinking) water shortage in many regions of the world. "Producing" drinking water is a life-saving health need; but most methods, such as desalination of sea water, reverse osmosis of polluted water or transporting water by ship, involve considerable energy expenditure.

The ethics issue and the ecological footprint both indicate the crucial importance of resource efficiency and the decisive role of industrialised countries in mitigation and adaptation measures for GCC. Yet we lack the metrics necessary to monitor the efficiency in using energy, material and water, at national and corporate level: we

\footnotetext{
${ }^{51}$ Kay (2008).
} 
lack the metrics to assess the value created from a tonne of material consumed, a tonne of water used, a tonne of oil equivalently spent. ${ }^{52}$ There is not even a differentiation in energy statistics between dissipative $\mathrm{CO}_{2}$ emissions and embodied $\mathrm{CO}_{2}$ emissions.

The ethics of fairness of the industrialised versus the LDCs demand a drastic reduction in the per capita resource consumption. Strategies to achieve a higher resource efficiency exist. ${ }^{53}$ This automatically would lead to a substantial reduction of world-wide $\mathrm{CO}_{2}$ emissions. GCC needs to be integrated into the larger concept of the ethics of sustainability. ${ }^{54}$

Industrial countries will have to change their economic models, based on increased resource throughput and increased world trade to create wealth, because it is incompatible with the objective of reduced resource consumption and reduced $\mathrm{CO}_{2}$ emissions. For durable goods and infrastructures, the feasible alternative is a more sustainable service economy based on knowledge and the management of physical assets (stock) in a regionalised economy, and applying loss prevention and risk management in order to maintain existing wealth and riches.

The insurance sector can play a key role of providing knowledge in loss prevention through risk engineering, as well as in sustainable investments and insuring sustainable technologies. A strict application of the principle of the insurability of technological innovation would increase the competitiveness of low-risk technologies, ${ }^{55}$ including bio- and nano-tech applications that are dematerialised and low carbon by nature. The insurance industry can also become a key player in both its investment and underwriting function with regard to PPPs, promoted by the UN Millennium goals, and Private Finance Initiatives (PFI). These vehicles enable to shift infrastructure projects from the public domain into the market economy. PFI are increasingly used for the construction and long-term operation of infrastructures by the same economic actor. Witness the Viaduc de Millau, a 78-year contract to design, finance, build and operate the bridge (until 2079), with a maintenance obligation until 2121, won in 2001 by Effiage, a French construction company.

But the political debate will have to choose between other options, such as economic models to promote a low-carbon economy (nuclear and renewables) or an energyefficient one (sufficiency and high resource efficiency), or between spending public research funds on adaptation measures to reduce the potential impact of GCC on people, or the quest for the scientific proof of the anthropogenic causes of GCC.

It might well be that a focus on a more holistic approach, best summarised today under the term sustainability, would bring the vision of the future closer to the definitions of "ecology" by Humboldt and Goethe in the 17th century.

A never ending discussion on the human influence on global climate change is of no use. Despite the many open questions, priority should be given to the options

\footnotetext{
52 Data on energy efficiency is available for some countries, and research on a databank on corporate resource efficiency as a guide for sustainable investments has begun in 2008 .

53 Giarini and Stahel (1989); Stahel (2006)

${ }^{54}$ See also WTO (2008).

55 Stahel (2003).
} 
which society has in dealing with a climate change that cannot be prevented but (its impact on mankind) hopefully restricted. This concerns also the cultural and social sciences. ${ }^{56}$

\section{References}

Allègre, C. (2007) Ma vérité sur la planète, Paris: Plon.

Baettig, M.B., Wild, M. and Imboden, D.M. (2007) 'A climate change index: Where climate change may be most prominent in the 21st century', Geophysical Research Letters 34: L01705.

Betts, R.A., Boucher, O., Collins, M., Cox, P.M., Falloon, P.D., Gedney, N., Hemming, D.L., Huntingford, C., Jones, C.D., Sexton, D.M.H. and Webb, M.J. (2007) 'Projected increase in continental runoff due to plant responses to increasing carbon dioxide', Nature 448: 1037-1041.

BHP-Hanser und Partner (2005) 'Kurzporträt der Abfallpolitik und der Abfall-wirtschaft in der Schweiz zwischen 1986 und 2002' (Abschnitt 2), in BHP-Hanser und Partner (eds) Evaluation der Abfallpolitik des Bundes 1986 und 2002, Zurich: BHP-Hanser und Partner.

CRO Forum (2006) Climate change \& tropical cyclones in the North Atlantic, Caribbean and Gulf of Mexico, CRO briefing, Emerging Risk Initiative Position Paper, available on http://www.cronetworks.org/ er.htm..

Die Welt (2008) 'Wider den Zeitgeist', Die Welt, 12 March, p. 9.

Gedney, N., Cox, P.M., Betts, R.A., Boucher, O., Huntingford, C. and Stott, P.A. (2006) 'Detection of a direct carbon dioxide effect in continental river runoff records', Nature 439: 835-838.

Giarini, O. and Stahel, W.R. (1989) The Limits to Certainty: Facing Risks in the New Service Economy, Dordrecht, NL: Kluwer.

von Goethe, J.W. (1779) Briefe aus der Schweiz, Paderborn: Schöningh.

von Goethe, J.W. (1825) 'Versuch einer Witterungslehre (1825)', in S. von Sachsen (ed) Goethes Naturwissenschaftliche Schriften, II. Abtheilung, 12. Band, Hermann Böhlaus Nachfolger: Weimar, pp. 74-96.

HM Treasury (2007) Stern Review on the Economics of Climate Change, London: HM Treasury, taken from http://www.hmtreasury.gov.uk/independent_reviews/stern_review_economics_climate_change/sternreview_index.cfm.

von Humboldt, A. (1858) Cosmos: A Sketch of the Physical Description of the Universe, Baltimore: The Johns Hopkins University Press.

Johnson, L. (2008) 'Optimists always have the last laugh', Financial Times, 9 April.

Kay, J. (2008) 'In times of complexity, common sense must prevail', Financial Times, 9 April.

Neue Zürcher Zeitung (2007a) 'Beschleunigte Bodenerosion in den Alpen', Neue Zürcher Zeitung, 13 September, p. 18.

Neue Zürcher Zeitung (2007b) 'Die deutsche Marine in immer ferneren Gewässern im Einsatz', Neue Zürcher Zeitung, 26 June, p. 7.

Neue Zürcher Zeitung (2008a) '2000-Watt-Gesellschaft - eine Metaphor oder ein anzustrebendes Ziel?', Neue Zürcher Zeitung, 8 April, p. 17.

Neue Zürcher Zeitung (2008b) 'Kalifornien droht auszutrocknen', Neue Zürcher Zeitung, 27 March, p. 7.

Rifkin, J. (2002) The Hydrogen Economy, New York: Tarcher/Putnam.

Simms, A., Johnson, V. and Smith, J. (2007) Chinadependence - The second UK interdependence report, London: New Economics Foundation.

Stahel, W.R. (1989) Catastrophic Risk Insurability: Risk Prevention and System Complexity — The Engineer and the Role of Insurance in Risk Management, Proceedings of the International Meeting "Catastrophes and Society" at Fundacion Mapfre, Madrid, October 24-26.

${ }^{56}$ Prof Klaus Stehr, director of the Institute for Coastal Research, GKSS Research Centre, Geesthacht, Professor for Meteorology at Hamburg University and Professor for cultural sciences at Zeppelin University at Friedrichshafen. 
Stahel, W.R. (1997a) 'The functional Economy, cultural and organizational change', in D.J. Richards (ed) The Industrial Green Game, Washington, DC: National Academy Press, pp. 91-100.

Stahel, W.R. (1997b) 'The service economy: Wealth without resource consumption?', Philosophical Transactions A 355: 1309-1319.

Stahel, W.R. (2003) 'The role of insurability and insurance', The Geneva Papers on Risk and Insurance Issues and Practice 28: 374-381.

Stahel, W.R. (2006) The Performance Economy, Basingstoke: Palgrave Macmillan, http://performanceeconomy.org.

The Washington Times (2007) 'The hottest year: 1934?', taken from http://www.washingtontimes.com/apps/ pbcs.dll/article?AID =/20070815/EDITORIAL/108150004.

Wilton Park Conference (2007) Climate and energy security - Towards a low carbon economy, Report on Wilton Park Conference, WP 866, 23-27 July 2007.

WTO (2008) Chair's Summary of the informal trade ministers' dialogue on climate change issues, World Trade Organization, WT/L/717, 25 January, Communication from Indonesia (post Bali).

\section{About the Author}

Walter R. Stahel is Vice Secretary General and Director of risk management research at The Geneva Association (International Association for the Study of Insurance Economics) since 1987. He is Visiting Professor at the Faculty of Engineering and Physical Sciences, University of Surrey and Guest Lecturer at Tohoku University, Japan. Since 1986, he has been in charge of the Research Programme on Risk Management and responsible for the M.O.R.E. seminar series (Managing Risk in the Economy). In 2003, he initiated the Annual Round Tables of Chief Risk Officers meetings (ART of CROs) and in 2005 the CRO Assemblies, for which he has been responsible since. The activities for Chief Risks Officers are organised jointly with Dr. Bruno Porro, chairman of the ART of CROs networks, and the CRO Assemblies alternatively with the CROs of Swiss Re and Munich Re. In 1983, together with Orio Giarini, he founded the Product-Life Institute in Geneva, which he is still managing today (http://product-life.org). His publications include The Performance Economy, 2006, published by Palgrave Macmillan, London (http://performance-economy.org), and The Limits to Certainty, Facing Risk in the New Service Economy, 1989/92, Kluwer Academic Publishers, Dordrecht (co-author Orio Giarini). 